\title{
Functional properties of germinated and non-germinated cereals : A comparative study
}

\author{
A. Siddiqua ${ }^{1}$, M. S. Ali ${ }^{1 *}$ and S. Ahmed ${ }^{2}$ \\ ${ }^{1}$ Department of Applied Chemistry and Chemical Technology, Faculty of Food Science and Technology, Chittagong Veterinary \\ and Animal Sciences University, Khulshi, Chittagong 4225, Bangladesh \\ ${ }^{2}$ Department of Food Processing and Engineering, Faculty of Food Science and Technology, Chittagong Veterinary and Animal \\ Sciences University, Khulshi, Chittagong-4225, Bangladesh
}

Received: 08 March 2018

Revised: 10 June 2018

Accepted: 03 December 2018

DOI: https://doi.org/10.3329/bjsir.v54i4.44573

\begin{abstract}
Cereal grains play an important role in human nutrition which is useful both for infants and adults. The practice of germination of cereal grains has become popular now-a-days. The present research was carried out to study the functional properties of germinated and non-germinated cereal flours (wheat, maize, sorghum). Bulk density and tapped density were increased in germinated maize but decreased in germinated sorghum and wheat. In germinated wheat and sorghum flour, carr index, foaming capacity, foaming stability and swelling capacity were increased but decreased in germinated maize flour. The water holding capacity of germinated wheat (GW), germinated maize (GM) and germinated sorghum (GS) $(0.93 \mathrm{~g} / \mathrm{g}, 1.91 \mathrm{~g} / \mathrm{g}$ and $2.06 \mathrm{~g} / \mathrm{g}$ respectively) was found as higher than the non-germinated wheat (NGW), non-germinated maize (NGM), non-germinated sorghum (NGS) $(0.5 \mathrm{~g} / \mathrm{g}, 1.27 \mathrm{~g} / \mathrm{g}$ and $1.16 \mathrm{~g} / \mathrm{g}$ respectively). Germination process increased oil holding capacity, emulsion activity, emulsion stability and acidity of all three flour samples. The oil holding capacity of maize flour $(1.75 \mathrm{~g} / \mathrm{g})$ was increased which was higher than the other samples. . Germinated sorghum had higher acidity $(0.97 \%)$ than other germinated cereals. The $\mathrm{pH}$ value of germinated wheat, maize and sorghum flour was decreased due to germination. The observed functional properties indicated that germinated flours may have important functional ingredients for preparation of different snacks, baked products and other food product.
\end{abstract}

Keywords: Germination; Functional properties; Cereals; Flour

\section{Introduction}

People all over the world depend on cereals for their regular and convenient source of energy and other nutrients. Wheat varieties grow well in winter season and temperature sensitive. It is the second most popular cereal after rice in Bangladesh. Wheat is significant source of mineral salts, calcium, magnesium, potassium, vitamin B, vitamin E, protein, starch, dietary fiber and phytochemicals (Shewry and Hey, 2015). Wheat is a major source of vegetable protein, having higher protein content especially gluten than other cereals. Over the last few years, wheat production did not increase sufficiently with the growth of population in Bangladesh (Hossain and Teixeira , 2013). To meet the demands of increasing population and for greater public awareness of celiac disease and gluten intolerance due to wheat consumption, wheat need to be replaced by other cereals such as maize, sorghum, legumes. Wheat is mainly used as a main ingredient for producing breads, biscuits cakes, pasta and noodles, breakfast cereals, weaning food and alcohol production by fermentation (Peňa et al., 2006). Maize is the third popular cereal after wheat and rice in Bangladesh. It is rich in highly digestible carbohydrate, high protein contents, cholesterol free oils, amino acids, pro-vitamin A, vitamin B, potash, phosphorus and beta-carotenes (Martin and Leonard, 1967). It is used for animal feeding, poultry feeding and popcorn production in Bangladesh. Maize can be used in the production of baked products, cakes, syrup, dextrose, alcoholic beverage, oil, fuel etc. Sorghum is the fifth most useful cereal grain worldwide. It can provide $83 \%$ carbohydrates, $10 \%$ protein, and $3.5 \%$ fat 
(Suarni, 2004). It is also rich source of vitamins such as riboflavin, thiamine, vitamin B6, and mineral contents including iron, manganese and dietary fiber which are beneficial for our digestive system (Musa et al., 2009). It is mainly used for livestock feeding. It can be used for making flatbreads, cakes, porridge etc. The strong flavor of sorghum can be removed by processing. The anti-nutritional factors of sorghum are polyphenols, phytic acid and tannin which affect the human digestive system (Towo et al., 2006). Germination is a spontaneous change in physiology, morphology and chemistry which are responsible for changing the functional properties of cereals. Germination of grains increases bio-active compounds, hydrolytic enzyme synthesis, proteins, vitamins, minerals, essential amino acid contents, total sugars, crude fiber and also shelf life of cereal grains and reduces starch components (Zomora and Fields, 1979). Germination also decreases bulkiness, dry matter content, starch and anti-nutrients in cereals such as phytate and some flavonoid components (Ahmed et al., 2006). During germination partial hydrolysis of starch, protein, fat degradation increases the digestibility of starch, fat and protein. Germination increases the functional properties of legumes and seeds (Sosulski et al., 1976). Water absorption capacity decreased and fat absorption capacity increased in three varieties of malted millets (Agarwal et al., 2013). Cauhan and Singh (2013) found that bulk density was decreased and water absorption index was increased with germination for amaranthus flour. Germination of maize more than 3 days decreased the bulk density of maize flour (Otutu et al., 2014). Now-adays consumers of developed countries are aware health problems caused by different diet and for this reason it is a great challenge for food industries to make nutritious foods having sufficient nutrients and bio-active compounds with high quality in terms of specific properties such as functional and nutritional properties. Functional properties play an important role in the physical behavior of cereal grains (Enwere and Ngoddy, 1986). Functional characteristics of food help to predict how they affect the taste, flavor, mouth feel and appearance of food products and how protein, fat, carbohydrate and fiber may behave in specific system. The aim of this study was to prepare germinated cereals anc evaluate the effects of germination on functional properties of different cereals.

\section{Materials and methods}

\section{Sample collection}

This experimental study was conducted at the Quality Control and Analytical Laboratory of the Faculty of Food Science and Technology, Chittagong Veterinary and Animal Sciences University, Chittagong, Bangladesh. The study samples (maize, white sorghum and wheat) were collected from the local market of Chittagong. Collected samples were transported to laboratory for further processing. The fresh grains were germinated and processed into flour using standard method (Blessing and Gregory, 2010).

\section{Preparation of germinated flour}

Collected grains were washed and soaked in water at room temperature for 24 hour. Then grains were kept at $35^{\circ} \mathrm{C}$ for 42 hour for germination. The optimum germination temperature of maize, sorghum and wheat grains have been reported as $28-35^{\circ} \mathrm{c}$ (Kun, 1988) and germination rate usually increases until the time reaches 42-72 hour (Adedeji et al., 2014). Based on the previous studies, germination time and temperature were chosen for this study. After germination the grains were dried in cabinet dryer at $65^{\circ} \mathrm{C}$ for 9 hours followed by dehulling. The germinated grains were milled to make flour and packed in airtight polyethylene bags .The packed germinated flour were stored at room temperature for further analysis (Fig.1).

\section{Preparation of non-germinated flour}

Grains were washed and dried at $65 \mathrm{C}$ for 9 hour in cabinet dryer. Then grains were milled to find fine flour and packed in airtight polyethylene bags for further analysis (Figure 1).

\section{Estimation of functional properties}

The germinated and non-germinated flour samples were examined for functional properties such as bulk density (BD, $\mathrm{g} / \mathrm{ml})$, tapped density (TD, g/ml), carr index (CI, g/ml), water holding capacity (WHC, g/g), oil holding capacity (OHC, g/g), swelling capacity (SC, g/g), foaming capacity (FC, \%), foaming stability (FS,\%), emulsion activity (EA, $\%$, emulsion stability(ES, \%), pH and acidity (\%). Bulk density, tapped density and carr index for flour samples were determined according to the method described by Musa et al. (2009). pH and acidity of the study samples were determined using standard method (AOAC, 2005), while water and oil holding capacities were investigated by the method of Beuchat (1977). The emulsion activity and emulsion stability were determined by the method developed by Yasumatsu et al. (1972). The method developed by Coffmann and Garciaj (1977) was used for determining foaming capacity and foaming stability of the study samples. Swelling capacity of the flour samples were determined by the method established by Leach et al. (1959) with modification. 


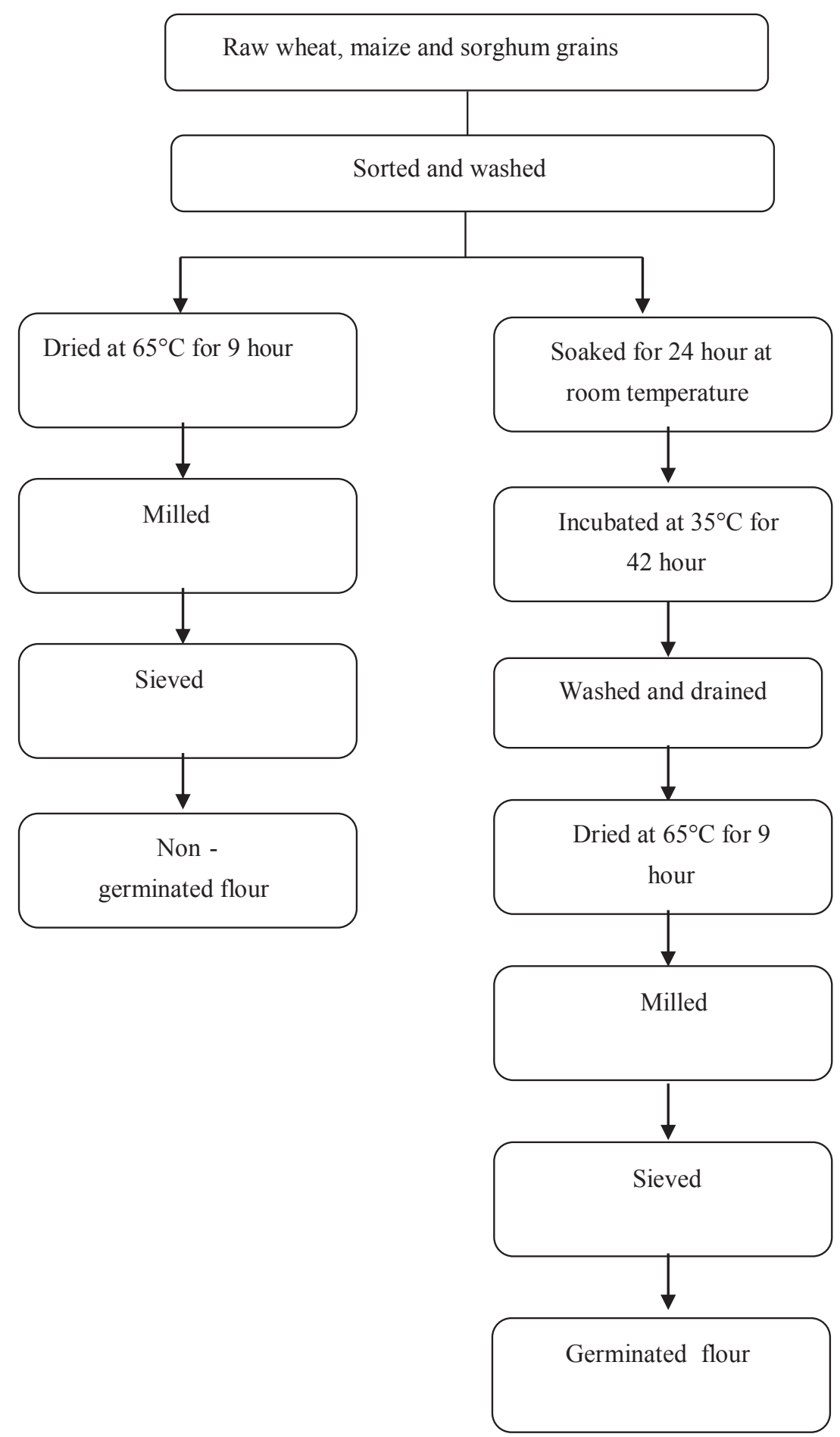

Fig. 1. Preparation of germinated and non-germinated flours (wheat, maize and sorghum) 


\section{Statistical analysis}

Results generated in this study were expressed as mean \pm standard deviation of three independent replications by using MS excel-2007.

\section{Results and discussion}

\section{Effects of germination on functional properties}

The bulk density for germinated wheat (GW), germinated maize (GM), and germinated sorghum (GS) were found to be $0.51 \mathrm{~g} / \mathrm{ml}, 0.49 \mathrm{~g} / \mathrm{ml}$, and $0.42 \mathrm{~g} / \mathrm{ml}$ respectively while bulk density for non-germinated wheat (NGW), non-germinated maize (NGM), and non-germinated sorghum (NGS) were reported $0.56 \mathrm{~g} / \mathrm{ml}, 0.43 \mathrm{~g} / \mathrm{ml}$ and $0.48 \mathrm{~g} / \mathrm{ml}$ respectively (Table I). The tapped density for GW, GM, and GS were $0.58 \mathrm{~g} / \mathrm{ml}, 0.58 \mathrm{~g} / \mathrm{ml}, 0.53 \mathrm{~g} / \mathrm{ml}$ respectively while tapped density for NGW, NGM, and NGS were found $0.62 \mathrm{~g} / \mathrm{ml}, 0.54 \mathrm{~g} / \mathrm{ml}$ and $0.56 \mathrm{~g} / \mathrm{ml}$ respectively (Table I). The study results indicated that the values of bulk density, tapped density increased due to germination for maize but decreased in case of germinated sorghum (GS) and germinated wheat $(\mathrm{GW})$. This present study result was very much similar with some previous studies (Otutu et al. 2014; Ocheme, 2015; Imtiaz, 2011). Bulk density can be affected by different factors such as preparation, treatment and storage of the grains. Lower bulk density might be for softening the grains

Table I. Functional profile comparison of germinated flours with non-germinated flours

\begin{tabular}{|c|c|c|c|c|c|c|}
\hline $\begin{array}{l}\text { Functional } \\
\text { Parameters }\end{array}$ & $\begin{array}{c}\mathrm{GW} \\
(\mathrm{mean} \pm \mathrm{SD})\end{array}$ & $\begin{array}{c}\mathrm{GM} \\
(\mathrm{mean} \pm \mathrm{SD})\end{array}$ & $\begin{array}{c}\mathrm{GS} \\
(\mathrm{mean} \pm \mathrm{SD})\end{array}$ & $\begin{array}{c}\mathrm{NGW} \\
(\mathrm{mean} \pm \mathrm{SD})\end{array}$ & $\begin{array}{c}\text { NGM } \\
(\text { mean } \pm \text { SD) }\end{array}$ & $\begin{array}{c}\text { NGS } \\
(\text { mean } \pm \text { SD })\end{array}$ \\
\hline $\begin{array}{l}\text { Bulk density } \\
(\mathrm{g} / \mathrm{ml})\end{array}$ & $0.51 \pm 0.006$ & $0.49 \pm 0.005$ & $0.42 \pm 0.005$ & $0.56 \pm 0.02$ & $0.43 \pm 0.005$ & $0.48 \pm 0.003$ \\
\hline $\begin{array}{c}\text { Tapped } \\
\text { density }(\mathrm{g} / \mathrm{ml})\end{array}$ & $0.58 \pm 0.004$ & $0.58 \pm 0.005$ & $0.53 \pm 0.002$ & $0.62 \pm 0.006$ & $0.54 \pm 0.004$ & $0.56 \pm 0.001$ \\
\hline $\begin{array}{c}\text { Carr index } \\
(\%)\end{array}$ & $12.07 \pm 3.00$ & $15.5 \pm 3.267$ & $20.7 \pm 4.67$ & $11.3 \pm 2.98$ & $20.37 \pm 3.45$ & $14.28 \pm 2.63$ \\
\hline $\begin{array}{c}\text { Water } \\
\text { holding } \\
\text { capacity }(\mathrm{g} / \mathrm{g})\end{array}$ & $0.93 \pm 0.27$ & $1.91 \pm 0.33$ & $2.06 \pm 0.037$ & $0.5 \pm 0.64$ & $1.27 \pm 0.68$ & $1.18 \pm 1.285$ \\
\hline $\begin{array}{l}\text { Oil holding } \\
\text { capacity }(\mathrm{g} / \mathrm{g})\end{array}$ & $1.75 \pm 0.12$ & $1.39 \pm 0.11$ & $1.12 \pm 1.27$ & $0.75 \pm 0.90$ & $1.07 \pm 0.09$ & $1.06 \pm 0.11$ \\
\hline $\begin{array}{l}\text { Emulsion } \\
\text { activity (\%) }\end{array}$ & $30.1 \pm 0.10$ & $32.6 \pm 0.13$ & $30.6 \pm 0.10$ & $23.7 \pm 0.29$ & $28.0 \pm 0.01$ & $29.26 \pm 0.12$ \\
\hline $\begin{array}{c}\text { Emulsion } \\
\text { stability }(\%)\end{array}$ & $30.6 \pm 2.26$ & $38.8 \pm 1.72$ & $56.5 \pm 4.02$ & $27.3 \pm 2.02$ & $36.8 \pm 1.23$ & $44.5 \pm 1.36$ \\
\hline $\begin{array}{c}\text { Foaming } \\
\text { capacity }(\%)\end{array}$ & $34.8 \pm 0.00$ & $16 \pm 0.01$ & $18.0 \pm 0.03$ & $16.0 \pm 0.02$ & $20.0 \pm 0.01$ & $10.0 \pm 0.01$ \\
\hline $\begin{array}{c}\text { Foaming } \\
\text { stability }(\%)\end{array}$ & $10.8 \pm 0.00$ & $4.0 \pm 0.06$ & $10.0 \pm 0.06$ & $4.0 \pm 0.05$ & $12.0 \pm 0.09$ & $8.0 \pm 1.0$ \\
\hline $\begin{array}{c}\text { Swelling } \\
\text { capacity }(\mathrm{g} / \mathrm{g})\end{array}$ & $3.0 \pm 0.03$ & $4.0 \pm 0.01$ & $4.94 \pm 0.06$ & $2.9 \pm 0.01$ & $4.2 \pm 0.02$ & $3.77 \pm 0.02$ \\
\hline
\end{tabular}

Note: Values are mean \pm standard deviation $(n=3) . G W=$ germinated wheat; $N G W=$ non-germinated wheat; GM= germinated maize; NGM= non-germinated maize; GS= germinated sorghum; NGS= non-germinated sorghum; 
during soaking which produced smaller flour particles after milling. During germination, breakdown of fat, starch and protein might be another cause of lower bulk density. Higher carr index (CI) was found in wheat and sorghum flour after germination. But in case of germinated maize (GM) flour carr index (CI) was decreased (Table I). Literatures revealed that foods with lower carr index (CI) have high flow ability and compressibility than foods with higher carr index (CI). Carr index (CI) can be affected by particle size, shape, surface criteria, density and porosity of flours. Values of carr index (CI) from $12 \%$ to $16 \%$ indicate good relative flow ability.

The study result showed that the water holding capacity (WHC) of germinated flour samples were higher than non-germinated flour samples (Table I). The highest water holding capacity (WHC) was found in germinated sorghum (GS) $(2.06 \mathrm{~g} / \mathrm{g})$ and the lowest was found in non-germinated wheat $(\mathrm{NGW})(0.5 \mathrm{~g} / \mathrm{g})$. This study result was supported by the study result conducted by Ocheme and co-workers (2015). Oyarekua and Adeyeye (2008) reported that higher water holding capacity (WHC) helps to improve softness, bulkiness, consistency of products and reduces viscosity.
The oil holding capacity (OHC) was increased in all germinated flour samples (Table I). The study findings were very much similar to the study done by Ocheme and co-workers (2015). Higher oil holding capacity (OHC) improves the taste, flavor and lipophilicity of the food products. The higher oil holding capacity (OHC) might be due to the solubilization and dissociation of protein during germination (Agarwal et al., 2013). According to this investigation all germinated samples have stronger affinity for oil and also for water.

The emulsion activity (EA) and emulsion stability (ES) were found as highest for germinated maize (GM) $(32.60 \%$ and $38.8 \%$ respectively) and lowest for non-germinated wheat (NGW) (23.7\% and 27.3\% respectively) (Table I). The emulsion activity (EA) and emulsion stability (ES) were increased by the action of hydrophobic protein activity (Kaushal et al. 2012).

Foaming capacity and stability of germinated wheat (GW) and germinated sorghum (GS) flour were increased (Table I). The lowest value of foaming capacity (FC) was found in non-germinated sorghum (NGS) while germinated wheat (GW) had the highest value. This present study result was almost similar to the results reported by Ocheme et al. (2015). But in case of germinated maize (GM), foaming

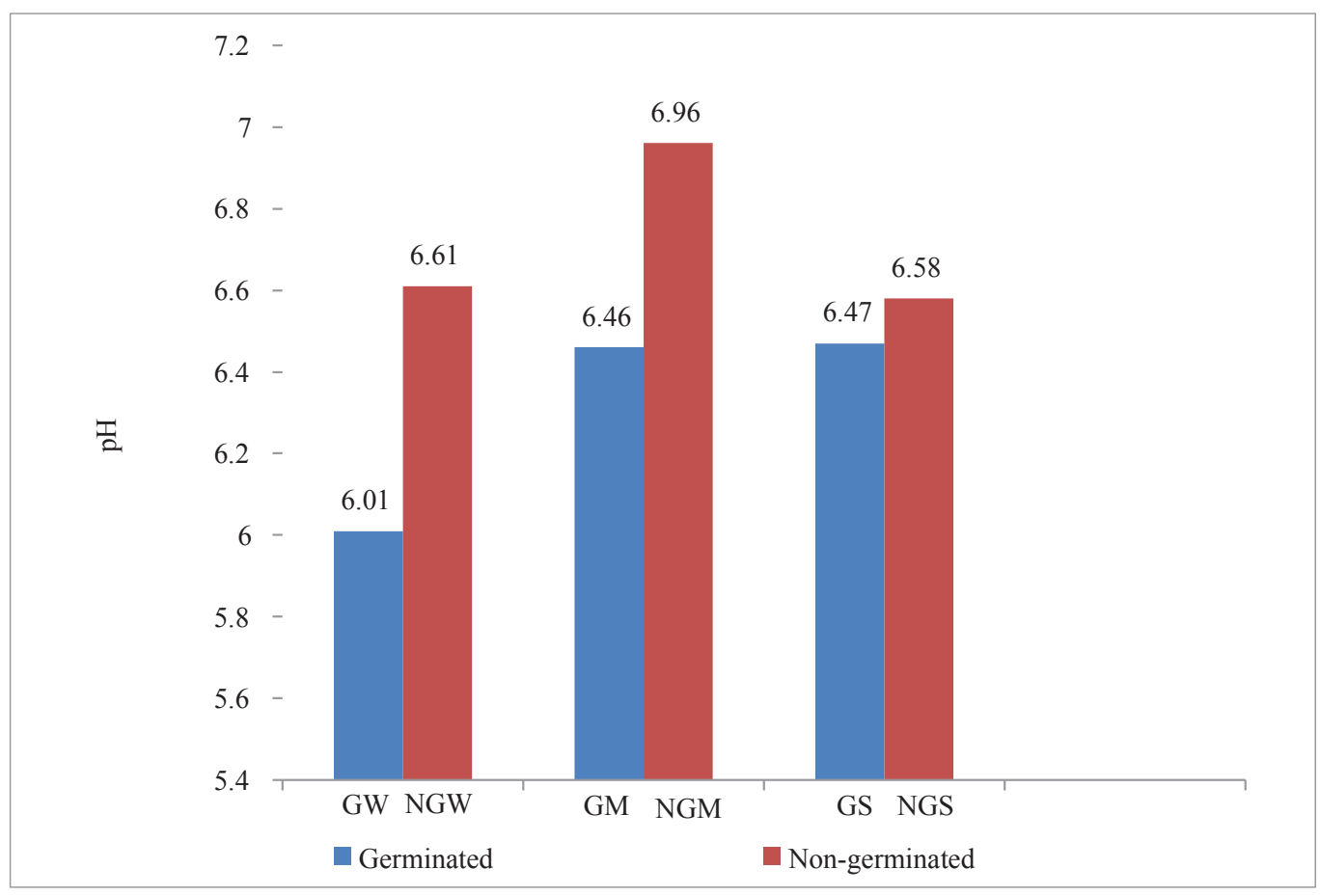

Fig. 2. Effect of germination on pH 
capacity (FC) and foaming stability (FS) were decreased. Similar result was investigated by Adedeji et al. (2014). Foaming capacity increases due to increased soluble protein contents during germination (Damodaran et al., 2008). Both foaming capacity and stability can be affected by protein type, $\mathrm{pH}$, surface tension and viscosity. Food ingredients with high foaming capacity (FC) and foaming stability (FS) can be useful for bakery products. Cereal flour with high foaming capacity (FS) and foaming stability (FC) improves the shelf life, consistency and appearance of products.

The swelling capacity was found as higher in germinated wheat (GW) and germinated sorghum (GS) flour. But in case of germinated maize (GM) flour it was found lower (Table I). The results were parallel with some previous studies (Ocheme et al. 2015). Swelling capacity was increased which might be due to degradation of fat, fiber and starch-lipid complex of flour during germination. Presence of amylase and amylopectin due to degradation of starch might be also responsible for increasing swelling power of germinated cereals. High swelling capacity makes cereal useful to be act as thickener in liquid food products.
$\mathrm{pH}$ and acidity of germinated and non-germinated flour samples

The highest $\mathrm{pH}$ value was found in non-germinated maize (NGM) flour. The $\mathrm{pH}$ of the flour samples was decreased with germination process (Fig. 2) subsequently acidity was increased ranging from $0.6 \%$ to $0.97 \%$ (Fig. 3). This study finding showed parallel relationship with the study done by Onyeka and Obeleagu (2013).

\section{Conclusion}

This study reported that functional properties of cereals grains were improved a lot through germination. Therefore it may be one of the important techniques to increase the nutritional value of the cereal grains. Germinated cereal flour can be used for the production of bakery and confectionary products because of its good functional characteristics. Gluten free germinated maize and sorghum were found with good functional properties so these cereals can be used instead of gluten free ingredients which are commercially used for people with gluten intolerance and celiac disease.

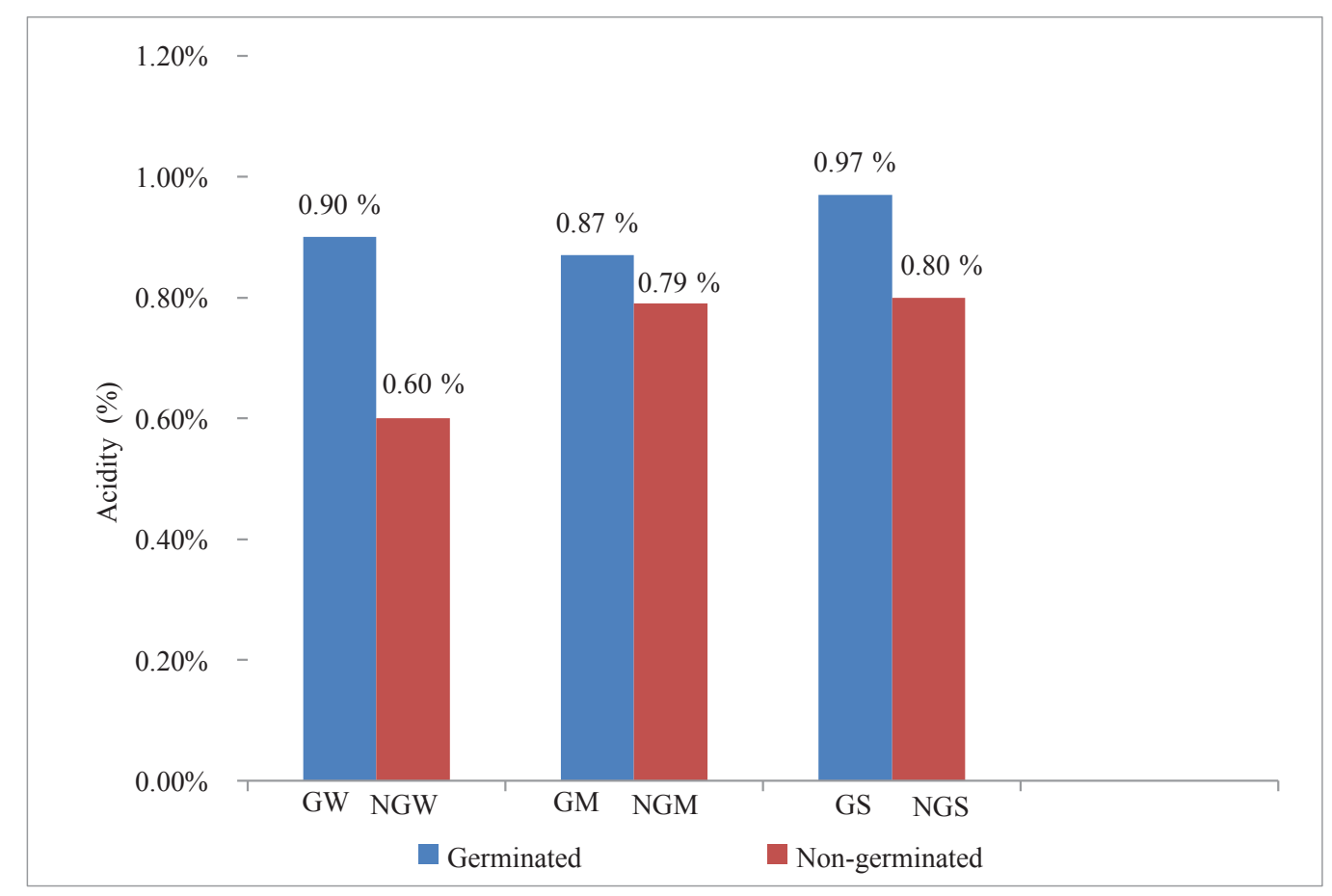

Fig. 3. Effect of germination on acidity 


\section{Acknowledgement}

The authors are grateful to the Quality Control and Analytical Laboratory of Chittagong Veterinary and Animal Sciences University, Bangladesh for providing laboratory support to carry out this study.

\section{References}

Abbas TEE and Musharaf NA (2008), The Effect of Germination of Low-Tannin Sorghum Grains on its Nutrient Contents and Broiler Chicks Performance, PakJ Nutri. 7(3): 470-474. DOI: 10.3923/pjn.2008.470.474

Adedeji OE, Oyinloye OD and Ocheme OB (2014), Effects of germination time on the functional properties of maize flour, Afr J Food Sci. 8(1): 42-47. doi: org/10.5897/AJFS 2013.1106.

Agrawal D, Upadhyay A and Nayak PS (2013), Functional Characteristics of Malted Flour of Foxtail, Barnyard and Little Millets, Annals. Food Science and Technology 14(1): 44-49.

Ahmed MD, Hamid RA, Ali ME and Hassan AB (2006), Proximate Composition, Antinutritional Factors and Protein Fraction of Guar Gum Seeds are Influenced by Processing Treatment, Pak J Nutri. 5(5): 481-484. DOI: $10.3923 /$ pjn.2006.481.484

AOAC (2005). Official method of Analysis of the Association of Official Analytical Chemists. $18^{\text {th }}$ Ed. Washington DC.

Beuchat LR (1977), Functional and electrophoretic characteristics of succinylated peanut flour protein, J Agric Food Chem. 25(2): 258-261. DOI: 10.1021/jf60210a044

Blessing IA and Gregory IO (2010), Effect of Processing on the Proximate Composition of the Dehulled and Undehulled Mungbean (Vigna radiate (L.) Wilczek), Pak J Nutri. 9(10): 1006-1016. DOI: 10.3923/ pjn.2010.1006.1016

Chauhan A and Singh S (2013), Influence of Germination on Physico-chemical Properties of Amaranth (Amaranthus Spp.) Flour, Int J Agric Food Sci Technol. 4(3): 215-220.

Coffmann CW and Garciaj VV (1977), Functional properties and amino acid content of a protein isolate from mung bean flour, Int J Food Sci Technol. 12(5): 473-484. DOI: 10.1111/j.1365-2621.1977.tb00132.x
Damodaran S, Parkin KL and Fennema OR (2008), Fennema's Food Chemistry. $4^{\text {th }}$ Ed. (CRS Press, London), pp 781-793.

Enwere NJ and Ngoddy PO (1986), Effect of heat treatment on selected functional properties of cowpea flour, Trop Sci. 26: 223-232.

Hossain A and Teixeira da silva JA (2013), Wheat production in Bangladesh: its future in the light of global warming, AoB PLANTS.5 : pls042. DOI: 10.1093/ aobpla/pls042.

Imtiaz H, Burhanuddin M and Gulzar MA (2011), Evaluation of weaning foods formulated from germinated wheat and mungbean from Bangladesh, Afr J Food Sci. 5(17): $897-903$. DOI: $10.5897 /$ AJFS 11.180

Kaushal P, Kumar V and Sharma HK (2012), Comparative study of physiochemical, functional, antinutritional and pasting properties of taro (Colocasia esculenta), rice (Oryza sativa), pigeon pea (Cajanus cajan) flour and their blends, LWT-Food Sci Technol. 48(1): 59-68. DOI: org/10.1016/j.lwt.2012.02.028

Kun E (1988). Cereals. Ankara University, Agriculture faculty press, Ankara.

Leach HW, McCowen LD and Schoch TJ (1959), Structure of the starch granule-Swelling and solubility patterns of various starches, Cereal Chem. 36: 534-544

Martin JH and Leonard WH (1967). Principles of field crop production. 2th Ed. (The Macmillan company, New York).

Musa H, Muazu J, Lorenz K and Appolonia BD (2009), Cereal sprouts: composition, nutritive value and food applications, CRC Crit Rev Food Sci Nutr. 13(4): 353-385. DOI: org/ 10.1080/1040839800952795.

Ocheme OB, Lawal G, Zakari UM and Adedeji OE (2015), Effect of functional properties and degree of starch gelatinization of sorghum flour, J Food Res. 4(2): 159-165. DOI: 10.5539/jfr.v4n2p159

Onyeka EU and Obeleagu OS (2013), Production and evaluation of specialty bread from sprouted mixed-grains, $A f r$ $J$ Food Sci. 7(4): 63-70. DOI: org/ 10.5897/ AJFS12.122 
Otutu OL, Ikuomola DS and Oloruntoba RO (2014), Effect of sprouting days on the chemical and physicochemical properties of maize starch, Am J Res Com. 2(6): 131-149. www.usa-journals.com, ISSN: 2325-4076

Oyarekua MA and Adeyeye EI (2008), Comparative Evaluation of the Nutritional Quality, Functional Properties and Amino Acid Profile of Co-fermented Maize/Cowpea and Sorghum Cowpea Ogi as Infants Complementary Food, Asian J Clin Nutri. 1: 31-39. DOI: $10.3923 /$ ajen.2009.31.39

Peňa E, Bernardo A, Soler C and Jouve N (2006), Do tyrosine crosslinks contribute to the formation of the gluten network in common wheat (Triticum aestivum L.) dough?, J Cereal Sci. 44(2): 144-153. DOI: org/10.1016/j.jcs.2006.05.003

Shewry PR and Hey SJ (2015), The contribution of wheat to human diet and health, Food ener sec. 4(3): 178-202. DOI: $10.1002 /$ fes 3.64

Sosulski F, Humbert ES, Bui K and Jones JD (1976), Functional Properties of Rapeseed Flours, Concentrates and Isolates, $J$ Food Sci. 41(6): 1349-1352. DOI: 10.1111/j.1365-2621.1976.tb01168.x
Suarni (2004), The utilization of sorghum flour as processed food (Pemanfaatan tepung sorgum untuk produk olahan), J Litbang Pertanian 23(4): 145-151.

Towo E, Matuschek E and Svanberg U (2006), Fermentation and enzyme treatment of tannin sorghum gruels: effect on phenolic compounds, phytate and in vitro accessible iron, Food Chem. 94(3): 369-376. DOI: org/10.1016/j.foodchem.2004.11.027

Yasumatsu K, Sawada K, Moritaka S, Misaki M, Toda J, Wada T and Ishii K (1972), Whipping and Emulsifying Properties of Soybean Products, Agric Biol Chem. 36(5): $719-727 . \quad$ DOI: $\quad$ org $/ 10.1080 /$ 00021369.1972 .10860321

Zamora AF and Fields ML (1979), Nutritive Quality of Fermented Cowpeas (Vigna sinensis) and Chickpeas (Cicer arietinum), J Food Sci. 44(1): 234-236. DOI: 10.1111/j.1365-2621.1979.tb10049.x 